\title{
Transformation of Public Administration of the Social and Economic Policy in Ukraine by the Example of the Healthcare Reformation
}

\author{
Natalia V. Tomchuk-Ponomarenko ${ }^{1 *}$, Ganna M. Lozova ${ }^{1}$, Lesia O. Pashniuk ${ }^{2}$, Tetiana \\ Krasnopolska ${ }^{3}$
}

\author{
${ }^{1}$ Department of Economic Theory, Macro and Microeconomics, Taras Shevchenko National University of Kyiv, Kyiv, Ukraine \\ ${ }^{2}$ Deputy Director for Economics of Selyshchanskyi Granite Quarry, Ltd, Kyiv, Ukraine \\ ${ }^{3}$ Department of Political Theories, National University "Odessa Law Academy", Odessa, Ukraine
}

Received: $14 / 11 / 2020$

Accepted: 05/01/2021

Published: 20/03/2021

\begin{abstract}
In the article, a problem is set regarding urgent transformation of the public administration of the social and economic policy of Ukraine under the healthcare reformation. The problem seems to be urgent because the Ukrainian national healthcare management system differs from similar systems in most developed countries due to a unique characteristic. The point is that at the highest legislative level, the state guarantees its citizens free medical care, although in practice, this provision remains partially declarative. And this should be a target of reformation. Today, the Ukrainian healthcare system, based on the centrally controlled principles, is facing a deep crisis, therefore the public administration model should be changed, and the healthcare system be radically reformed. Basing on modeling methods, expert survey, mathematical statistics, the following results have been obtained: a formulated list of problems, an offered model for the healthcare system management in Ukraine considering that the process should be transformed. These results can lay the groundwork for the development of a real strategic plan, when the task of "clearing the problematic area" to be solved in stages, according to the actual urgency of certain problems from the point of view of increasing the efficiency of the healthcare system reformation in Ukraine.
\end{abstract}

Keywords: Health protection system, healthcare problems, public administration, transformation, reformation, model

\section{Introduction}

Population health is believed to be the most important factor of economic, political, social development, and the healthcare system is the most important component of public administration, based on state policy aimed to ensure the Ukrainian citizens' rights to health protection, medical care and medical insurance [1]. Considering the provisions of Ukrainian legislation, it should be noted that the Ukrainian national healthcare management system differs from similar systems in most developed countries due to a unique characteristic. The point is that the Constitution of Ukraine guarantees citizens free medical care at state and municipal healthcare institutions, although this constitutional provision is partially declarative in practice. At the end of February 2020, government officials promised a free diagnosis and treatment for those Ukrainians exposed to COVID-19 at public health facilities [2]. Today, in some cases people with suspected COVID-19 have to pay for tests, as well as citizens returned to the country from abroad have to either get tested for COVID-19, which costs about 30 euros, or voluntarily stay under observation. Currently Ukraine is turned out to fail to provide high-quality medical care in full even under a high epidemiological threat, and restrictive measures adopted in the country in March 2020 restrained the epidemic for a while, but loosening quarantine measures in Ukraine showed authorities' confusion about the virus spread challenges.
This situation is typical not only for Ukraine, countries leading in social, economic, and humanitarian development are known to stumble ahead with the coronavirus spread as well. However, unlike these states, the Ukrainian realities show the lack of proper material, technical and financial support for epidemiological measures and therapeutic methods; lack of a system of strategic forecasting and medical care planning in emergency. In general, the situation in countering the Covid-19 outbreak in Ukraine has once again shown the local healthcare system degraded, the state medicine management system failed, and the current healthcare management model to be urgently transformed. Thus, the goal of the article is to study how to improve the state healthcare management in Ukraine in order to increase the system efficiency, to develop a management model considering that the management process needs to be transformed.

\section{Literature Review}

Scientists and politicians who initiated transformation processes in several countries devoted their works to issues associated with improving the national health system efficiency [3 - 5]. Analysis of these works shows that healthcare management seems to be the most significant social component part of the public administration irrespective of the management model adopted in a particular country. Thus some countries, from the United States to Vietnam, are currently

*Corresponding author: Natalia V. Tomchuk-Ponomarenko, PhD in Economics, Associate Professor of Taras Shevchenko National University of Kyiv, Kyiv, Ukraine. E-mail: tomchuk@knu.ua 
reforming their national health systems. At the same time, the foreign experience in the healthcare system reformation described in the foreign authors' papers [6-9] does not fully correspond to the Ukrainian economy potential and long-term traditions of the Semashko system based medicine management. Issues relating to public management were described by Ukrainian scientists [10 - 15].

The scientists noted that the rapid development of science and information technology fundamentally changes the economics, the state's role in the complicated transformation processes is actualized [15] despite the policy of the people's welfare growth is the primary task to be solved by almost every state with policy aimed to implement the principles of sociallyoriented market economy development [16]. Supporting these positions (regarding the state's participation in transformation processes, in particular, in the medicine reformation), we point out that the issues of the reformation content, the state's participation in the medicine management, the introduction in Ukraine of a system for provision of paid healthcare services need to be further justified because they are quite complicated and the scientific works do not clear up externalities, affecting medicine reformation and the state's responses to current challenges for the medicine management system.

\section{Research Methods}

The general scientific methodology was used during the research, particularly, theoretical methods (analysis, synthesis, classification) to reveal the current state of Ukrainian medicine, to structure the field of problems to be solved in transformation of the government control system. Two main statistical methods are used in data analysis: descriptive statistics, which summarize data from a sample using indexes such as the mean or standard deviation, and inferential statistics, which draw conclusions from data that are subject to random variation. Structural and systemic analysis was used to generalize the facts determining the state of the issue under review in order to specify it basing on national statistics. The modeling method was used in investigation of the dynamics, the domestic medicine development, the expert survey methods allow to structure the entire range of problems faced by the state transformation management, the results were statistically processed using standard methods of statistics and cluster analysis in Statistics 6.0 software.

\section{Results and Discussion}

Currently, Ukraine is facing a difficult task associated with the transformation of government control over the social and economic policy in general, and the healthcare management system, in particular. The solution to this problem is associated with the healthcare system reformation choosing a management model that meets current social and economic realities formed in Ukraine at the beginning of the $21^{\text {st }}$ century. The reform is required because the situation in Ukrainian medicine is complicated (if not critical) in almost all parameters which determine the quality of medical care. Thus the reformation seems to be required since the end of the last century, as it is obvious today. Currently, medical reformation is believed to be one of the main tasks of the Ukrainian government, which believes that national medicine based on the Soviet model built by M.A. Semashko (1874-1949) has lost its effectiveness and fails to satisfy population's demand for accessible medical care and qualitative medical services. This model was built as a multi-level healthcare system with a clearly differentiated structure of service providers and assumed state budget funding only, government control through the central planning system [17].

For a long historical period in Ukraine, under centrally controlled economy, this model satisfied all social relation participants, however, it actually became incapacitated with the country's transition to market relations, which was especially obvious in the last decade, when the Ukrainian healthcare system faced a crisis situation. Almost 10 years ago, in 2011, the National Institute for Strategic Research noted in the executive summary "On Priority Areas for Improving the Domestic Healthcare Sector" that the total financing for healthcare from the state and local budgets increases annually, but its per capita size remains very low. This increases population's personal expenses (both official and unofficial) and replaces free medical care with fee-based medical services. Experts also noted the imperfection of the structural and organizational model of the healthcare system management applicable in Ukraine since Soviet times, indicating that in the country, along with the Ministry of Health of Ukraine, several other medical services, systems, ministries, and departments existed (and still do). They are financed by $42.3 \%$ of the state health budget. The irrational use of available resources, low accessibility to quality health services, low staffing, imperfect legislation regulating the healthcare system activities in the country seem to be problematic as well [18].

Table 1: Statistical data characterizing the healthcare system in Ukraine in 2008 - 2017 (compiled according to (State Statistics Service of Ukraine [20]; 2018 Fertility, mortality and life expectancy tables)

\begin{tabular}{|c|c|c|c|c|c|}
\hline \multirow[t]{2}{*}{ Years } & \multicolumn{5}{|c|}{ Statistical indicators } \\
\hline & $\begin{array}{l}\text { Population } \\
\text { (million people) }\end{array}$ & $\begin{array}{l}\text { Population morbidity, } \\
\text { registered cases of diseases - } \\
\text { total (million people) }\end{array}$ & $\begin{array}{l}\text { Mortality rate in } \\
\text { Ukraine (per } \\
1000 \text { people) }\end{array}$ & $\begin{array}{l}\text { Number of doctors } \\
\text { of all specialties } \\
\text { (thousand total) }\end{array}$ & $\begin{array}{l}\text { Number of } \\
\text { hospitals } \\
\text { (thousand total) }\end{array}$ \\
\hline 2008 & 46.6 & 32.8 & 15.1 & 223 & 2.9 \\
\hline 2009 & 46.4 & 32.4 & 15.1 & 222 & 2.8 \\
\hline 2010 & 46.1 & 33.0 & 15.1 & 225 & 2.8 \\
\hline 2011 & 46.0 & 33.0 & 15.2 & 225 & 2.5 \\
\hline 2012 & 45.8 & 32.3 & 15.3 & 224 & 2.4 \\
\hline 2013 & 45.6 & 31.1 & 15.4 & 217 & 2.2 \\
\hline 2014 & 45.5 & 31.0 & 15.6 & 217 & 1.8 \\
\hline 2015 & 45.4 & 26.8 & 15.8 & 186 & 1.8 \\
\hline 2016 & 42.9 & 26.7 & 16.1 & 186 & 1.7 \\
\hline 2017 & 42.7 & 27.3 & 16.1 & 187 & 1.7 \\
\hline $\begin{array}{l}\text { Dynamics } \\
2017 / 2008,(\%)\end{array}$ & -9.1 & -20.1 & +6.6 & -19.2 & -70.5 \\
\hline
\end{tabular}


Moreover, in our opinion, since 1991, i.e. since Ukraine gained independence, the medical management system kept degrading, objectively decreasing in the population's life quality. Assuming that the global health strategy aims to enhance the quality of life, to reduce the population's morbidity and mortality [19], proceeding from this position, the system of public administration of the health system in Ukraine can be evaluated by the parameters of its effectiveness, based on actual statistics. If we turn to the national statistics of Ukraine (indicators of the healthcare system development in the country were updated in 2017) [20] (Table 1), then, nevertheless, the problematicity of the system functioning can be ascertained. As it can be seen from the above table, in the period from 2008 to 2017 , the number of the population of Ukraine decreased by $9.1 \%$, while the incidence rate decreased by $20.1 \%$ in the period under review. In principle, the decreased morbidity can be assessed positively, however, we take into account that this indicator reflects only registered cases of morbidity, despite, according to analytical studies, every second patient in Ukraine refuses treatment or postpones it due to money shortage. $94 \%$ of patients consider the high cost of treatment to be the main problem, and the percentage of those who resort to selfmedication reaches almost 70\% [21]. Also, it should be noted that in the period under review, the mortality rate increased significantly (by 6.6\%), while the total number of medical personnel decreased by almost $20.0 \%$, and the number of medicine institutions decreased by more than $70.0 \%$. Thus, the statistics data show the problematicity of the healthcare system in all the studied parameters. The statistical data also allow to assess the general state of the healthcare system in Ukraine (on the basis of "degradation/development"), expressed in standard units (s.u.), based on the following mathematical model:

((Population quantity/ morbidity) $\mathrm{x}$ (Population quantity / mortality))/

(Population/Doctors quantity) x (Population/hospital facilities quantity))

Below are the calculations showing a certain idea of the healthcare system dynamics in the country over a ten-year period, from 2008 to 2017 :

2008: $((46.6 / 32.8) \times(46.6 / 15.1)) /((46.6 / 223) \times(46.6 / 2.9))$ $=1.3 \mathrm{~s} . \mathrm{u}$

2009: $((46.4 / 32.4) \times(46.4 / 15.1)) /((46.4 / 222) \times(46.4 / 2.8))$ $=1.2 \mathrm{~s} . \mathrm{u}$
2010: $((46.1 / 33.0) \times(46.1 / 15.1)) /((46.1 / 225) \times(46.1 / 2.8))$

$=1.2$ s.u.

2011: $((46.0 / 33.0) \times(46.0 / 15.2)) /((46.0 / 224) \times(46.0 / 2.6))$

$=1.1 \mathrm{~s} . \mathrm{u}$.

2012: $((45.8 / 32.3) \times(45.8 / 15.3)) /((45.8 / 217) \times(45.8 / 2.5))$

$=1.0 \mathrm{~s} . \mathrm{u}$.

2013: $((45.6 / 31.1) \times(45.6 / 15.4)) /((45.6 / 217) \times(45.6 / 2.4))$

$=1.0$ s.u.

2014: $((45.5 / 31.0) \times(45.5 / 15.6)) /((45.5 / 186) \times(45.5 / 2.2))$

$=0.8$ s.u.

2015: $((45.4 / 26.8) \times(45.4 / 15.8)) /((45.4 / 186) \times(45.4 / 1.8))$ $=0.7$ s.u.

2016: $((42.9 / 26.7) \times(42.9 / 16.1)) /((42.9 / 186) \times(42.9 / 1.7))$ $=0.7$ s.u.

2017: $((42.7 / 27.3) \times(42.7 / 16.1)) /((42.7 / 187) \times(42.7 / 1.7))$ $=0.7$ s.u.

The figure shows a trend line allowing to assess the rate of the Ukrainian healthcare system degradation in the period under review, and, in general, indicating a crisis in the public health management system (Fig. 1). As it is seen, according to the calculations, the healthcare system in Ukraine in 2008 2017 slipped, while the general state of the healthcare system in its effectiveness, staffing and medical support decreased by $53.8 \%(100.0 \% /(1.3 / 0.7)=53.8 \%)$. In this regard, a systemic imbalance in the existing model of Ukrainian healthcare can be indicated, destructive processes continue with threatening consequences for the entire national healthcare system. In 2018, this disappointing situation led to a medical reformation in Ukraine, aimed at the healthcare system transformation. It should be noted that in 2014, Ukraine adopted the National Health Reform Strategy for Ukraine for the period 2015-2020, which stated that the healthcare system in Ukraine is unwieldy and obsolete basing on the Semashko model with strict management and financing. This situation is caused by big disadvantages in the national healthcare system due to the lack of modernization, ignoring the population's needs, failure to use current global tendencies, ineffective system operation, and high corruption [22]. The management system should be transformed in three stages, according to the strategy developers' plan: short-term actions (2015-2016), mediumterm actions (2017-2018) and long-term actions (2018 and after). However, by mid-2020, the initial stage of reformation measures is not implemented yet.

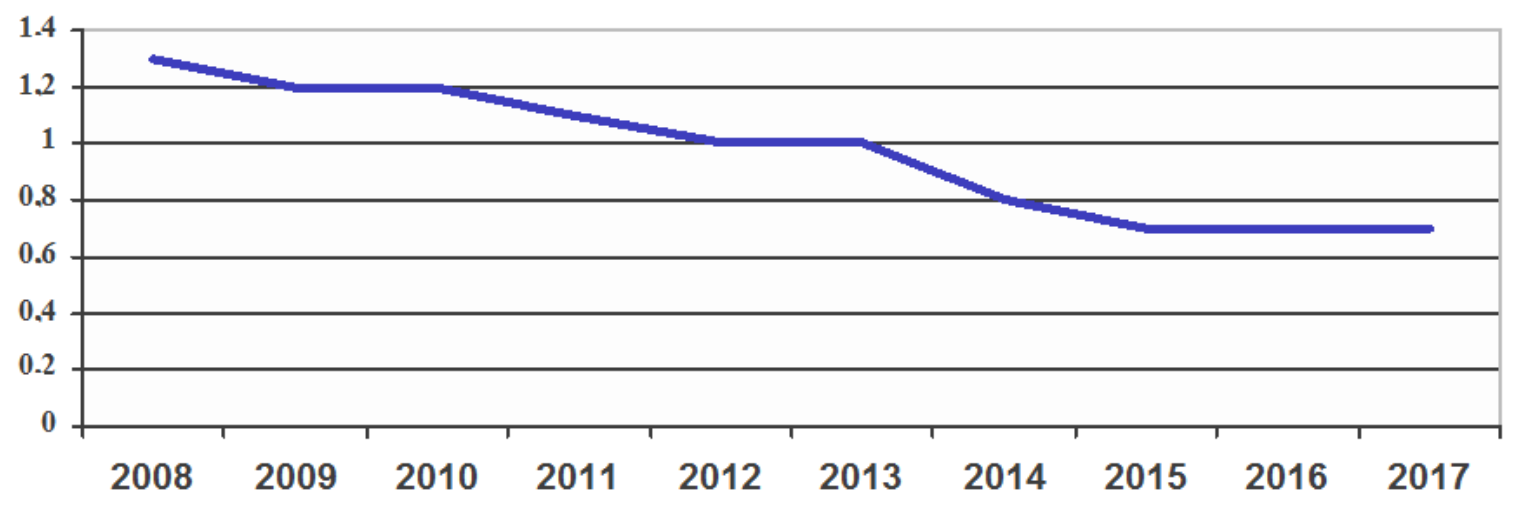

\section{:Standard unițs}

Figure 1: Rates of the healthcare system degradation in Ukraine in 2008 - 2017 
In particular, the issue related to the Constitution of Ukraine provisions regarding medical care seems unclear, its literal interpretation excludes any reform in the healthcare; key laws to facilitate the transition of the medical care system to the insurance medicine model have not been adopted; the National Agency for Health Financing has not been established; no policy has been developed to provide targeted benefits to lowincome and chronically ill patients, etc. To reveal problematic issues of the reformation, to determine externalities slowing transformation down, "a problematic field of reforming the Ukrainian medicine management system" was formulated based on the works by Ukrainian researchers $[23,24]$. Then the identified problems were appropriately assessed, a survey was conducted for the heads of 37 medical institutions in various regions of Ukraine, concerning reformation of the Ukrainian healthcare management system (Table 2). The data obtained during the survey were processed using Statistics 6 software (Fig. 2). This resulted in structuring main problems in the studied field of social relations using the "k-mean" indicator. As a result, the cluster structure of the problems that determine the conditions for medicine reformation in Ukraine was defined (Table 3).

Table 2: Generalized data for the analysis of problems determining the situation in the reformation of the Ukrainian medicine management (points)

\begin{tabular}{lllll}
\hline No. & Problems & Weight & $\begin{array}{l}\text { Problem } \\
\text { level }\end{array}$ & $\begin{array}{l}\text { Final value: weight } \\
\text { x problem level }\end{array}$ \\
\hline 1 & $\begin{array}{l}\text { A clear strategy for transforming the medicine management system, taking } \\
\text { into consideration national capabilities and resources }\end{array}$ & 4.83 & 4.78 & 23.08 \\
\hline 2 & A personnel pool system for job openings in the medicine management system & 3.78 & 3.78 & 14.3 \\
\hline 3 & An advanced training system for people involved in the medicine management & 3.89 & 3.67 & 14.2 \\
\hline 4 & A legislative basis for medical care provision under transformation & 3.72 & 3.72 & 13.8 \\
\hline 5 & $\begin{array}{l}\text { Experience in reforming the healthcare system, increasing the efficiency of } \\
\text { the decision implementation }\end{array}$ & 4.89 & 4.62 & 23.0 \\
\hline 6 & A system of responsibility of those who ensure the reform implementation & 3.35 & 3.35 & 11.2 \\
\hline 7 & A risk management system in medicine & 2.83 & 2.83 & 8.0 \\
\hline 8 & Conditions for public and private partnership in healthcare & 2.94 & 2.94 \\
\hline 9 & $\begin{array}{l}\text { Applied methods of public medicine management based on the best world } \\
\text { management practices }\end{array}$ & 3.02 & 3.19 & \multirow{2}{*}{9.6} \\
\hline 10 & $\begin{array}{l}\text { Political will and awareness of public officials of the required transition to a } \\
\text { new model of healthcare management }\end{array}$ & 4.02 & 5.0 & 20.1 \\
\hline 11 & $\begin{array}{l}\text { An effective model of financial support of medical institutions based on the } \\
\text { insurance medicine development }\end{array}$ & 2.94 & 4.78 & \multirow{2}{*}{14.05} \\
\hline 12 & Human resources for reformation & 3.12 & 3.78 & 11.8 \\
\hline 13 & Developed institutional environment for reformation & 2.18 & 2.18 & 4.8 \\
\hline 14 & Creation of conditions for development of a competitive field in medicine & 2.94 & 2.94 & 8.6 \\
\hline 15 & Development of a system of medical institutions of various ownership forms & 1.59 & 1.7 & 2.7 \\
\hline
\end{tabular}

Table 3: Clustering the problematic area of reformation of the management system of Ukrainian medicine (based on the results of the survey of the heads of medical institutions in Ukraine) Factor

\begin{tabular}{lll}
\hline \multicolumn{2}{l}{ Factor } & k-mean \\
\hline \multicolumn{2}{l}{ Segment 1 (problems that can be solved in the long term) } & 0.578315 \\
\hline 7 & Creation of a risk management system in medicine & 0.935559 \\
\hline 8 & Creation of conditions for public and private partnership in healthcare & 1.528265 \\
\hline 9 & Improving the public administration methods in medicine based on the best world management practices & 1.345075 \\
\hline 13 & Development of the institutional framework for the transformation & 0.935559 \\
\hline 14 & Creation of conditions for the development of a competitive field in medicine & 2.631483 \\
\hline 15 & Development of a system of medical institutions of various ownership forms & 0.647623 \\
\hline Segment 2 (problems that can be solved in the medium term) & 0.622106 \\
\hline 2 & Creation of a personnel pool system for job openings in the medicine management system & 0.370066 \\
\hline 3 & Creation of a system of skill improvement for people involved into the medicine management & 1.205669 \\
\hline 4 & Development of the legal framework for the medical care provision under transformation & 0.780836 \\
\hline 6 & Increasing the level of responsibility of those who ensure the reform implementation & 0.847594 \\
\hline 11 & $\begin{array}{l}\text { Improving the model of financial support for medical institutions based on the development of insurance } \\
\text { medicine }\end{array}$ & \multirow{2}{*}{0.606438} \\
\hline 12 & Developing human resources for reformation & 0.580833 \\
\hline Segment 3 (problems to be solved immediately) & \begin{tabular}{l} 
Creation of a clear strategy for transformation of the medicine management system, taking into account \\
\hline 1 \\
national capabilities and resources
\end{tabular} & \multirow{2}{*}{$\begin{array}{l}\text { Formation of political will and awareness of public officials of the required transition to a new model of } \\
\text { healthcare management }\end{array}$} \\
\hline
\end{tabular}




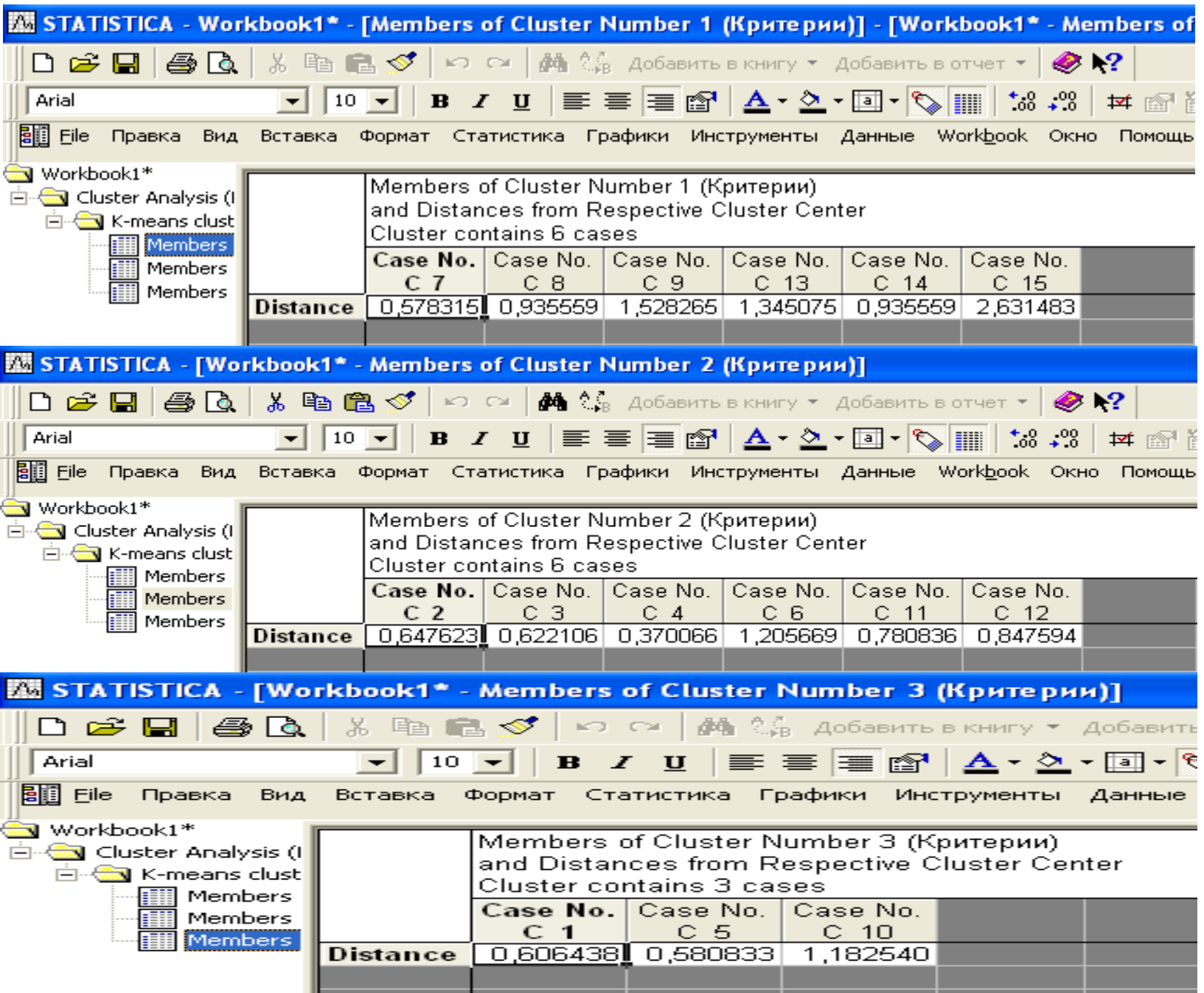

Figure 2: Results of cluster analysis of the problematic area in reformation of the Ukrainian medicine management system (based on the results of the survey of the heads of medical institutions in Ukraine) (2018 and after)

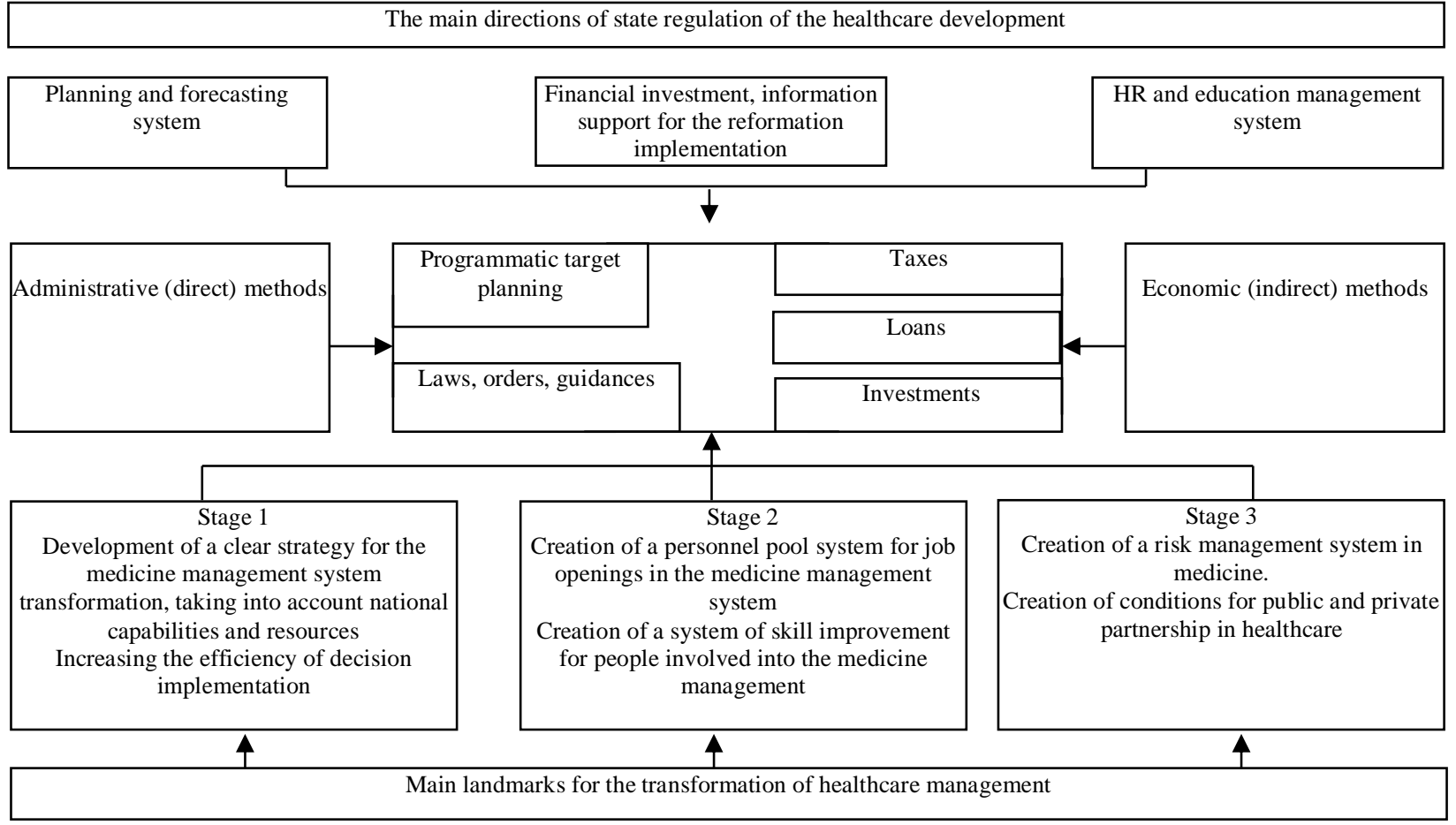

Figure 3: Model of the healthcare system management in Ukraine, taking into account the transformation stages 
The most significant result of this survey was in explanation by 35 out of the 37 heads of medical institutions of the transformation difficulties by failure of the Ukrainian officials related to the healthcare management to feel that the system needs to be radically and urgently transformed within the shortest terms, considering the actual social and economic situation in the country. Also, the heads ( 34 people) pointed out the low efficiency of the decision implementation, the lack of a clear strategy for transforming the healthcare management system, taking into account national capabilities and resources, and the lack of proper experience in Ukraine in reforming the area under study. Speaking about the last element of the problematic area of reforming the management system of Ukrainian medicine, we point out that in the absence of proper experience, developments of international organizations proved their effectiveness should be applied. In this regard, we'd like to mention that fifteen years ago (in 2005), WHO presented its vision of the transformation of the health management system based on the transition from universal goals to individual management objective [25]. This approach is currently consistent with the problems related to the strategic vector of transformation of the management system of Ukrainian medicine. In order to adapt the WHO structural scheme (Fig. 3) to the current conditions in Ukraine, it is necessary to link the key areas of the reformation with the strategic management guidelines through a system of appropriate management methods.

The approach allows combining the disparate and poorly structured methods to the healthcare system management in Ukraine, creating a truly effective strategy for transforming the management system, taking into account the phased reformation.

\section{Conclusion}

The issues of transformation of the public administration system under the healthcare system reformation have been studied herein. Materials and facts stipulated in the article allow to draw the following conclusions:

- Currently Ukraine is experiencing significant problems in the healthcare, unable to provide the population with quality medical care in full. This situation is associated with an outdated model of healthcare system management, formed in Ukraine under centrally controlled economy, and unable to function effectively in market relations. The current situation objectively requires the state medicine management to be transformed, the Ukrainian healthcare system to be reformed;

- Reformation of the Ukrainian medicine management system requires solving certain problems related to the legislative support of the transformation process, development of a clear reformation strategy, acceleration of the management system reformation, study of best practices in medicine reformation and integration of the best achievements in the national public administration system;

- The formulated list of problems and proposed model of healthcare system management in Ukraine (considering that the process should be transformed) can lay the groundwork for the development of a real strategic plan, when the task of "clearing the problematic area" can be solved in stages, according to the actual urgency, relevance of certain problems from the point of view of increasing the efficiency of the healthcare system reformation in Ukraine.

Summing up the article, we note that the issues of transformation of public administration of the healthcare system in Ukraine are being actualized against increased epidemiological risks. In this regard, Ukraine, as well as other countries, has to develop clear models of management of the entire social and economic policy under epidemiological danger and taken quarantine measures. The issues of establishment of appropriate institutions able to promptly react to the current situation, to reduce epidemiological risks, to ensure the public health protection seem urgent as well. Also, due to the high complexity of solving problems in the medicine, the absence of proper experience in reformation, the public authorities should pay attention to the global experience of medicine reformation, choose a management model contributing to the preservation of the traditional "social orientation" of Ukrainian medicine and considering the market nature of the provision of medical services. This list of problematic issues defines the content for further research aimed at improving the state healthcare management mechanisms in Ukraine.

\section{Ethical issue}

Authors are aware of, and comply with, best practice in publication ethics specifically with regard to authorship (avoidance of guest authorship), dual submission, manipulation of figures, competing interests and compliance with policies on research ethics. Authors adhere to publication requirements that submitted work is original and has not been published elsewhere in any language.

\section{Competing interests}

The authors declare that there is no conflict of interest that would prejudice the impartiality of this scientific work.

\section{Authors' contribution}

All authors of this study have a complete contribution for data collection, data analyses and manuscript writing.

\section{References}

[1] Constitution of Ukraine. Bulletin of the Verkhovna Rada of Ukraine. 1996. URL: https://iportal.rada.gov.ua/uploads/documents/27396.pdf

[2] Peshkova A. Expensive coronavirus: how much does Covid-19 treatment cost in Ukraine and who should pay for it. 2020. URL: https://112.ua/statji/dorogoy-koronavirus-skolko-stoit.

[3] Li Ling, Fu Hongqiao. China's healthcare system reform: Progress and prospect. 2017. URL: https://onlinelibrary.wiley.com/doi/epdf/10.1002/hpm.2424

[4] Obama B. United States healthcare reform progress to date and next steps. $2016 . \quad$ URL: https://jamanetwork.com/journals/jama/fullarticle/2533698

[5] Nguyen Thi Bich Thuan, Lofgren C, Lindholm L, Nguyen Thi Kim Chuc. Choice of healthcare provider following reform in Vietnam/BMC Health Services Research.2008;8:162-174.

[6] Oborsky AY, Chistyakov AA, Prokopyev AI, Nikolyukin SV, Chistyakov KA, Tararina LI. The national mentality in the history of philosophy. XLinguae. 2018; 11(3): 158-165.

[7] Firsova I, Vasbiev D, Prokopyev AI, Zykin ES, Matvienko VV. Development of consumers' behaviour business model on energy market. International Journal of Energy Economics and Policy. 2018; 8(4): 227-233.

[8] Cornilov GA, Ilkevich KB, Shalomova EV, Kartushina IG, Musharatsky ML, Mashkin NA, Altukhov SA. Features of alcohol consumption motives and practices by full-time and part-time training students. Journal of Environmental Treatment Techniques. 2019; 7(3): 438-444.

[9] Bayanova AR, Vodenko KV, Sizova ZhM, Chistyakov AA, Prokopiev AI, Vasbieva DG. A philosophical view of organizational culture in contemporary universities. European Journal of Science and Theology. 2019; 15(3): 121-131

[10] Radysh YF. State policy in health protection. Kiev: NADU. 2013.

[11]Bilynska MM, Vasyuk NO, Firsova OD. Medical and social principles of the public administration in health protection. Kyiv: NADU. 2018. 
[12] Karamyshev DV. The concept of innovative transformation: interbranch approach to reformation of the health protection system (state-management aspects). Kharkiv: Publishing House KharRI NADU "Magister. 2004.

[13] Korolenko VV, Yurochko TP. Personnel policy in health protection of Ukraine in the context of the European integration. National Academy for Public Administration under the President of Ukraine. Kiev: KIM. 2018.

[14] Nizalova O, Shapoval N. Medical insurance: panacea or euthanasia for the Ukrainian health protection system. URL: http:// ru.espreso.tv/blogs/2015/03/30/medychne_strakhuvannya_panaceya_chy_evtanaziya_dlya_ukrayinskoyi_systemy_okhoro ny_zdorovya

[15] Lozova GM. Assessment of impact of the innovative policy on formation of the national competitiveness of Ukraine. Theoretical and applied issues of economy. 2014; 1: 392-400.

[16] Tomchuk-Ponomarenko NV. Formation of the main directions of the economy of well-being and living standards of the population. Bulletin of Taras Shevchenko National University of Kyiv.2014;11(164): 59-65.

[17] Rybakova EO. Organizational and legal foundations of the Soviet healthcare system: 1917-1936: dissertation for $\mathrm{PhD}$ in legal sciences. Moscow. 2010.

[18] On Priority Areas for Improving the Domestic Healthcare Sector. Executive summary. $2011 . \quad$ URL: https://niss.gov.ua/doslidzhennya/socialna-politika/schodoprioritetnikh-napryamiv-vdoskonalennya-vitchiznyanoi-sferi.

[19] World Health Organization. Global strategy for dengue prevention and control 2012-2020. World Health Organization. 2012. URL: https://apps.who.int/ iris/handle/10665/75303.

[20] State statistics service of Ukraine. Tables of birthrate, mortality and average life duration for 2018. Statistical collection. Kiev: State statistics service of Ukraine. State statistics service of Ukraine. 2020. URL: http://www.ukrstat.gov.ua/.

[21] Stefanyshina O, Susan K. Results of the research "F(r)ee medicine". Kiev: Nauk. Dumka.2017.

[22] National strategy of reformation of the healthcare system in Ukraine for the period of 2015-2020. URL: https://moz.gov.ua/uploads/0/691-strategiya.pdf

[23] Voronenko YuV, Goyda NG. Healthcare reformation: success and obstacles. Modern medical technology. 2013;2:24-26

[24] Muzyka IS. Reformation of health protection: problems, analysis, implementation directions (by example of the Carpathian region of Ukraine). Economics and the national economy management.2016;2:38-43.

[25] World Health Organization. Report on healthcare in Europe 2009. Health and healthcare systems. 2010. URL: https://www.euro.who.int/_data/assets/pdf_file/0009/82386/E93 103.pdf 